\title{
MANAJEMEN WAKTU, BIAYA DAN SDM PROYEK KONSTRUKSI PADA PEMBANGUNAN GEDUNG RUANG KULIAH FIA UNIVERSITAS BRAWIJAYA MALANG DENGAN MENGGUNAKAN METODE PERT DAN PDM
}

\author{
Anugerah Fakhrur Rozy ${ }^{1}$, Ode R.G.W. ${ }^{2}$ \\ ${ }^{1,2}$ Jurusan Teknik Sipil Fakultas Teknik Universitas Muhammadiyah Malang \\ Alamat korespondensi : Jalan Raya Tlogomas 246 Malang 65144
}

\begin{abstract}
Project managers always want to find a method which can improve quality and control to deal with the number of activities that tend to increase. To improve the quality of planning and control of the building project B FIA UB used a method, and the method used herein is Project Evaluation and Review Technique (PERT) Method and Presedence Diagram Method (PDM) with a software program tool Microsoft Office Project 2003. Completion time planning the optimal project using PERT and PDM is 303 days with a total cost Rp 16,278,036,000.00 (including contractors profit $+10 \%$ PPN). From the calculation of the target analyte project completion time $T(d)$, shows that the possibility of the project is completed on time / period of 303 days (normal time) only by 50\%. Whereas if the duration / Project Completion period plus $3 S$ (three times the standard deviation) is 303 days + $14.13=317.13$ days, then it is likely the project is completed on time / period of 317.13 days at $99 \%$ (on time).
\end{abstract}

Keywords: Time, Cost, SDM, PERT Method, PDM, Microsoft Office Project 2003.

\begin{abstract}
Abstrak
Manajer proyek selalu ingin mencari metode yang dapat meningkatkan kualitas dan kontrol untuk menangani jumlah kegiatan yang cenderung meningkat. Untuk meningkatkan kualitas perencanaan dan pengendalian proyek gedung B FIA UB menggunakan metode, dan metode yang digunakan disini adalah Evaluasi Proyek dan Review Technique (PERT) Metode dan presedence Diagram Method (PDM) dengan alat program perangkat lunak Microsoft Office Project 2003. waktu Penyelesaian perencanaan proyek yang optimal dengan menggunakan PERT dan PDM adalah 303 hari dengan biaya total Rp 16,278,036,000.00 (termasuk kontraktor keuntungan $+10 \%$ PPN). Dari hasil perhitungan target analit waktu penyelesaian proyek $\mathrm{T}(\mathrm{d})$, menunjukkan bahwa kemungkinan proyek selesai tepat waktu / periode 303 hari (waktu normal) hanya sebesar 50\%. Sedangkan jika periode durasi / Penyelesaian Proyek ditambah 3S (tiga kali standar deviasi) adalah 303 hari $+14.13=317,13$ hari, maka kemungkinan proyek selesai tepat waktu / periode 317,13 hari pada $99 \%$ (tepat waktu).
\end{abstract}

Kata kunci: Waktu, Biaya, SDM, Metode PERT, PDM, Microsoft Office Project 2003.

\section{PENDAHULUAN}

Manajemen Proyek adalah suatu upaya untuk merencanakan, mengorganisir, memimpin dan mengendalikan sumberdaya berupa manusia, waktu dan biaya, teknologi dan material untuk mencapai sasaran yang telah didefinisikan dan ditentukan dengan jelas serta seifisien mungkin sehingga diperoleh hasil yang sesuai spesifikasi, dengan melibatkan sekelompok orang yang masing-masing mempunyai kemampuan dan keahlian tertentu.
Pada proyek pembangunan gedung B yang terdiri dari enam lantai ruang kuliah Fakultas Ilmu Administrasi (FIA) Universitas Brawijaya Malang dengan luas $5700 \mathrm{~m}^{2}$ adalah bertujuan sebagai sarana penunjang proses perkuliahan pada Fakultas Ilmu Administrasi Universitas Brawijaya. Sehingga proyek tersebut membutuhkan berbagai macam sumber tenaga dengan skala besar dan mempunyai banyak aktifitas serta membutuhkan biaya yang besar juga. Banyaknya SDM, aktifitas serta biaya yang besar itulah maka dibutuhkan perencanaan dan pengendalian proyek yang cermat dan teliti. 
Untuk meningkatkan kualitas perencanaan dan pengendalian proyek digunakan suatu metode, dan metode yang akan dibahas disini adalah metode Proyek Evaluation and preview Technique (PERT) dan metode Presedence Diangram Method (PDM) dengan mengambil objek penelitian pada proyek pembangunan gedung B FIA Universitas Brawijaya Malang dengan alat bantu program software Microsoft Office Project 2003.

Adapun tujuan dari studi ini adalah :

- Untuk mengetahui berapa durasi/waktu aktifitas pekerjaan penyelesaian proyek pembangunan gedung B FIA yang efektif dan efisien dengan menggunakan metode PERT dan PDM dengan alat bantu Ms. Project agar dapat berjalan sesuai dengan rencana yang ditetapkan.

- Untuk mengetahui berapakah waktu, biaya dan SDM optimal yang dibutuhkan dengan menggunakan metodePERT dan PDM.

\section{Sistem Manajemen Waktu Pada Proyek Konstruksi}

Pengelola proyek selalu ingin mencari metode yang dapat meningkatkan kualitas dan pengendalian untuk menghadapi jumlah kegiatan yang cenderung bertambah. Beberapa metode yang sering digunakan diantaranya metode Lintasan Kritis (CPM), Teknik Evaluasi dan Peninjauan Proyek (PERT), dan Metode Preseden Diagram (PDM). Metode yang dipergunakan dalam manajemen waktu ini yaitu Metode Teknik Evaluasi dan Peninjauan Proyek (PERT) dan Metode Preseden Diagram (PDM).

\section{Metode Teknik Evaluasi dan Review Proyek (PERT)}

Metode PERT direkayasa untuk menghadapi situasi dengan kadar ketidak pastian yang tinggi pada aspek kurun waktu kegiatan.

Metode PERT memakai pendekatan yang menganggap bahwa kurun waktu kegiatan tergantung pada banyak faktor dan variasi, sehingga lebih baik perkiraan diberi rentang, yaitu dengan memakai tiga angka estimasi. Ketiga waktu estimasi tersebut adalah (Iman Soeharto, Manajemen Proyek Dari konseptual Sampai Operasional, 1995:228):1. $\mathrm{a}=$ kurun waktu optimistik (optimistic duration time) Waktu tersingkat untuk menyelesaikan kegiatan bila segala sesuatunya berjalan mulus. Waktu demikian diungguli hanya sekali dalam seratus kali bila kegiatan tersebut dilakukan berulang-ulang dengan kondisi yang hampir sama. 2. $\mathrm{m}=$ kurun waktu paling mungkin (most likely time)ulang dengan kondisi yang hampir sama.3. $\mathrm{b}=$ kurun waktu pesimistik (pessimistic duration time)

Waktu yang paling lama untuk menyelesaikan kegiatan, yaitu bila segala sesuatunya serba tidak baik. Waktu demikian dilampaui hanya sekali dalam seratus kali, bila kegiatan tersebut dilakukan berulang-ulang dengan kondisi yang hampir sama. Setelah tiga. angka estimasi tersebut diketahui maka langkah selanjutnya adalah merumuskan hubungan ketiga angka tersebut menjadi satu angka yang disebut dengan waktu yang diharapkan (expected duration time). Angka te dirumuskan sebagai berikut:

Deviasi Standart Kegiatan $(\mathrm{S})=(1 / 6)(\mathrm{b}-a)$

Varians Kegiatan V (te) $=S^{2}=[(1 / 6)(b-a)]^{2}$

\section{Target Waktu Penyelesaian}

Untuk mengetahui kemungkinan/kepastian mencapai target kurun waktu penyelesaian proyek maka hubungan antara waktu yang diharapkan (TE) dengan target $\mathrm{T}(\mathrm{d})$ pada metode PERT dinyatakan dengan $\mathrm{z}$ dan dirumuskan sebagai berikut:

Deviasi $\mathrm{z}=\mathrm{T}(\mathrm{d})-\mathrm{TE}, \mathrm{S}$

Dimana: $\mathrm{T}(\mathrm{d})=$ Target waktuTE $=$ Jumlah te kegiatan kritis $\mathrm{V}(\mathrm{TE})=$ Jumlah $\mathrm{V}($ te $)$ kegiatan kritis

\section{Metode Preseden Diagram (PDM).}

Dalam penentuan jaringan kerja (network) dengan PDM, jalur kritis dan slack atau float penulis menggunakan diagram Preseden. Hal ini digunakan untuk mengatasi adanya rangkaian kegiatan yang tumpang tindih (overlapping) dan berulang-ulang sehingga memerlukan garis dummy yang banyak sekali, diagram preseden digram preseden terdapat empat macam konstrain yaitu (Iman Soeharto, 1995:241), yaitu:

- $\quad$ Konstrain Selesai ke Mulai - FS 
Konstrain FS (Finish to Start) memberikan penjelasan hubungan antara mulainya suatu kegiatan dengan selesainya kegiatan terdahulu.

- $\quad$ Konstrain Mulai ke Mulai - SS

Konstrain SS (Start to Start) memberikan penjelasan hubungan antara mulainya suatu kegiatan dengan mulainya kegiatan terdahulu.

- Konstrain Selesai ke Selesai - FF

Konstrain FF (Finish to Finish) memberikan penjelasan antara suatu kegiatan yang dapat diselesaikan setelah kegiatan pendahulunya selesai.

- $\quad$ Konstrain Mulai ke Selesai - SF

Konstrain SF (Start to Finish) memberikan penjelasan hubungan antara suatu kegiatan dapat diselesaikan setelah kegiatan sebelumnya dimulai.

\section{METODE PENELITIAN}

Metode yang digunakan adalah analisa data.Analisa tersebut meliputi waktu dan biaya berdasarkan dua macam metode yaitu metode PERT dan PDM pada proyek pembangunan gedung kuliah FIA Universitas Brawijaya Malang.Dalam penentuan jaringan kerja (network) penulis menggunakan aturan metode PDM.Sedangkan dalam menentukan durasi waktu pada tiap-tiap pekerjaan penulis menggunakan aturan metode yang kedua yaitu metode PERT.

\section{Langkah Kerja}

Adapun langkah-langkah kerja dalam menganalisa waktu, SDM dan biaya dengan menggunakan metode PERT dan PDM adalah sebagai berikut:

- Pengumpulan data-data dan informasi dari proyek yaitu : gambar proyek, RAB proyek, time schedule.

- Menyusun RAB baru yang mengacu pada gambar kerja dari proyek dengan bantuan daftar analisa pekerjaan SNI 2007 dan daftar upah dan bahan satuan pekerjaan tahun 2012.

- Menentukan variabel a, m, b. Kemudian menentukan durasi penyelesaian pekerjaan, te(expected duration time)dengan menggunakan metode PERT yang dipakai sebagai durasi/kurun waktu tiap-tiap jenis
- $\quad$ Setelah diketahui durasi dari tiap-tiap pekerjaan kemudian menghitung kebutuhan SDM dari setiap pekerjaan tersebut.

- Menyusun/membuat jaringan kerja berdasarkan durasi dari metode PERT dan menentukan hubungan saling ketergantungan antar kegiatan/pekerjaan (constrain) dengan PDM.

- Menginput data-data yg diperlukan berdasarkan jaringan kerja metode PDM dengan menggunakan program Microsoft Office Project 2007 sehingga diketahui lintasan/jalur kritis dari output berupa Gantt chart dan network diagram.

- Menganalisa penggunaan SDM apakah sudah optimal atau tidak, yaitu dikatakan optimal jika penggunaan SDM dalam hal ini tenaga kerja tidak fluktuatif atau mengahasilkan grafik mendekati kurva distribusi normal. Jika dirasa belum optimal maka dibuat jaringan kerja (jadwal) baru sehingga tercapai hubungan jadwal-SDM yang optimal/efisien.

- Menentukan hitungan maju (ES dan EF), hitungan mundur (LS dan LF), waktu penyelesaian proyek (jumlah te jalur kritis), float, dan jalur kritis. Selanjutnyamenganalisa besarnya nilai deviasi standart $(\mathrm{S})$ dan varians (V(TE)).

- Menghitung prosentase tercapainya target waktu penyelesaian proyek (Td) sebagai analisa probabilitas waktu penyelesaian proyek secara keseluruhan.

- Pelaporan hasil analisa dan pembahasan

- Kesimpulan.

\section{HASIL DAN PEMBAHASAN}

\section{Analisa Harga Satuan Pekerjaan}

Harga satuan pekerjaan diperoleh dengan cara mengalikan koefisien dengan harga satuan bahan dan upah perhari kemudian dijumlahkan. Tujuannya adalah untuk mengetahui berapa besarnya biaya yang diperlukan baik bahan/material maupun upah pada setiap satu satuan pekerjaannya.

Harga Satuan Pekerjaan $=$ Koefisien $\mathrm{x}$ Harga $\mathrm{RAB}=$ Volume $\mathrm{x}$ Harga Satuan Pekerjaan 


\section{Analisa Rencana Anggaran Biaya}

Rencana Anggaran Biaya Proyek adalah rencana pengeluaran biaya proyek yang dianalisa dari perincian macam pekerjaan, dapat diketahui dengan mengalikan volume total setiap pekerjaan dengan jumlah satuan harga tiap pekerjaan. Sehingga total biaya setiap pekerjaan dapat diketahui dan PPN juga dapat diketahui. Rekapitulasi Rencana Anggaran Biaya dapat dilihat pada Tabel 1 :

\section{Analisa Waktu Pekerjaan/Penjadwalan}

http://ejournal.umm.ac.id/index.php/jmts/article/view/2036

Perencanaan Jaringan Kerja Dengan Metode PDM Lingkup pekerjaan yang akan disusun menjadi network diagram dalam penelitian ini berasal dari kegiatan-kegiatan proyek yang telah ada. Berdasarkan daftar kegiatan tersebut kemudian dilakukan penyusunan kembali dari setiap jenis pekerjaan menjadi mata rantai dengan urutan kegiatan yang sesuai dengan logika kegiatan yang dapat dilaksanakan secara tumpang tindih. Data yang diambil pada analisis ini adalah daftar kegiatan yang dilaksanakan pada Proyek Pembangunan Ruang Kuliah FIA Universitas Brawijaya Malang. Hubungan Saling Ketergantungan Antar Kegiatan Dapat dilihat pada tabel 2.

Tabel 1 Rekapitulasi RAB

\begin{tabular}{|c|c|c|c|}
\hline No & Pekerjaan & Jumlah & Total \\
\hline I & Pekerjaan struktur & & Rp 10,137,813,338.29 \\
\hline $\mathrm{A}$ & Pondasi & $\operatorname{Rp} 1,230,897,338.29$ & \\
\hline B & Struktur lantai 1 & Rp $1,042,453,334.79$ & \\
\hline $\mathrm{C}$ & Struktur lantai 2 & $\operatorname{Rp} 1,357,652,429.44$ & \\
\hline $\mathrm{D}$ & Struktur lantai 3 & Rp $1,307,387,098.43$ & \\
\hline E & Struktur lantai 4 & $\operatorname{Rp} 1,311,551,481.00$ & \\
\hline $\mathrm{F}$ & Struktur lantai 5 & $\operatorname{Rp} \quad 1,249,715,789.10$ & \\
\hline G & Struktur lantai 6 & $\operatorname{Rp} 1,289,354,633.76$ & \\
\hline $\mathrm{H}$ & Pekerjaan kuda-kuda & $\mathrm{Rp} \quad 906,786,465.54$ & \\
\hline I & Pekerjaan atap & $381,014,681.19$ & \\
\hline $\mathrm{J}$ & Lain-lain & $61,000,000.00$ & \\
\hline II & Pekerjaan arsitektur & & $\mathrm{Rp} \quad 4,508,607,234.54$ \\
\hline A & Pekerjaan persiapan & $54,368,000.50$ & \\
\hline B & Lantai 1 & $\operatorname{Rp} 1,002,727,779.61$ & \\
\hline $\mathrm{C}$ & Lantai 2 & $523,514,155.23$ & \\
\hline $\mathrm{D}$ & Lantai 3 & $602,385,745.36$ & \\
\hline E & Lantai 4 & $510,782,247.49$ & \\
\hline $\mathrm{F}$ & Lantai 5 & $472,945,753.52$ & \\
\hline G & Lantai 6 & $778,722,196.06$ & \\
\hline $\mathrm{H}$ & Pekerjaan instalasi pipa & $133,299,356.76$ & \\
\hline I & Pekerjaan m.e & $342,080,500.00$ & \\
\hline $\mathrm{J}$ & Telepon & $61,030,000.00$ & \\
\hline \multirow[t]{5}{*}{$\mathrm{K}$} & Fire alarm \& hydrant alarm & $26,751,500.00$ & \\
\hline & & Jumlah & Rp 14,646,420,572.83 \\
\hline & & Ppn. $10 \%$ & Rp $\quad 1,464,642,057.28$ \\
\hline & & Jumlah biaya total & $\operatorname{Rp} 16,111,062,630.12$ \\
\hline & & Dibulatkan & Rp $16,111,062,000.00$ \\
\hline
\end{tabular}

(Sumber: Data hasil perhitungan)

Tabel 2. Hubungan Saling Ketergantungan Antar Kegiatan

\begin{tabular}{clcclll}
\hline Kode & \multicolumn{1}{c}{$\begin{array}{c}\text { Uraian } \\
\text { Pekerjaan fia ub }\end{array}$} & Predecessors & Kode & Uraian & Predecessors \\
\hline A & Pek. Persiapan & & I13 & $\begin{array}{l}\text { Fire\&hydrant } \\
\text { alarm }\end{array}$ & I7,I8,I9(FS) \\
B & Pondasi & A(FS) & J & $\begin{array}{l}\text { STRUKTUR } \\
\text { LT.5 }\end{array}$ & F(FS) \\
C & Struktur lt.1 & B(FS) & K & STRUKTUR & LT.6 & J(FS) \\
\hline
\end{tabular}




\begin{tabular}{|c|c|c|c|c|c|}
\hline $\mathrm{D}$ & Srtuktur 1t.2 & $\mathrm{C}(\mathrm{FS})$ & $\mathrm{L}$ & $\begin{array}{l}\text { STRUKTUR } \\
\text { ATAP }\end{array}$ & $\mathrm{K}(\mathrm{FS})$ \\
\hline $\mathrm{E}$ & Struktur lt. 3 & $\mathrm{D}(\mathrm{FS})$ & M & ARSITEK Lt.4 & \\
\hline $\mathrm{F}$ & Struktur lt.4 & $\mathrm{E}(\mathrm{FS})$ & M1 & Kolom praktis & $\begin{array}{l}\text { J,G12,G13,G14,H9, } \\
\text { H10, H11,I11,I12 } \\
\text { I13,I14(FS) }\end{array}$ \\
\hline $\mathrm{G}$ & Arsitek lt.1 & & M2 & $\begin{array}{l}\text { Pasangan } \\
\text { dinding }\end{array}$ & $\mathrm{J}(\mathrm{FS})$ \\
\hline G1 & Pek. tanah & $\mathrm{E}(\mathrm{FS})$ & M3 & Balok Latei & $\mathrm{J}(\mathrm{FS}), \mathrm{M} 2(\mathrm{SS})$ \\
\hline $\mathrm{G} 2$ & Pas. Pond. batu kali & $\mathrm{E}(\mathrm{FS}), \mathrm{G} 1 \mathrm{FF}$ & M4 & $\begin{array}{l}\text { Kusen,pintu \& } \\
\text { jendela }\end{array}$ & $\mathrm{J}(\mathrm{FS}), \mathrm{M} 3(\mathrm{SS})$ \\
\hline G3 & Sloof \& kolom praktis & G2(FS) & M5 & $\begin{array}{l}\text { Pekerjaan } \\
\text { beton }\end{array}$ & $\mathrm{J}(\mathrm{FS})$ \\
\hline G4 & Pasangan dinding & G3(SS),G2(FS) & M6 & $\begin{array}{l}\text { Pekerjaan } \\
\text { Pemipaan }\end{array}$ & M4(FS) \\
\hline G5 & Balok Latei & G4(SS),G2(FS) & M7 & $\begin{array}{l}\text { Pek plesteran } \\
\text { dan cat }\end{array}$ & M1,M2,M5,M6(FS) \\
\hline G6 & Kusen,pintu \& jendela & G5(SS),G2(FS) & M8 & $\begin{array}{l}\text { Instalasi } \\
\text { pipa/sanitair }\end{array}$ & M4(FS) \\
\hline G7 & Pekerjaan beton & G6(FS) & M9 & $\begin{array}{l}\text { Pekerjaan } \\
\text { metal }\end{array}$ & M4(FS),M8(SS) \\
\hline G8 & Rioreling \& pemipaan & G6(FS) & M10 & Pekerjaan M.E & M7,M8,M9(FS) \\
\hline G9 & Pek plesteran dan cat & G7,G4(FS)-1 & M11 & $\begin{array}{l}\text { Instalasi } \\
\text { telephone }\end{array}$ & M7,M8,M9(FS) \\
\hline G10 & Instalasi pipa/sanitair & G8(FS) & M12 & $\begin{array}{l}\text { Fire \& hydrant } \\
\text { alarm }\end{array}$ & M7,M8,M9(FS) \\
\hline G11 & Pekerjaan metal & G7(FS),G9(SS) & $\mathrm{N}$ & ARSITEK Lt.5 & \\
\hline G12 & Pekerjaan M.E & G9,G10,G11(FS) & N1 & Kolom praktis & $\mathrm{K}(\mathrm{FS})$ \\
\hline G13 & Instalasi telephone & G9,G10,G11(FS) & $\mathrm{N} 2$ & $\begin{array}{l}\text { Pasangan } \\
\text { dinding }\end{array}$ & $\mathrm{K}(\mathrm{FS})$ \\
\hline G14 & Fire \& hydrant alarm & G9,G10,G11(FS) & $\mathrm{N} 3$ & Balok Latei & $\mathrm{K}(\mathrm{FS}), \mathrm{N} 2(\mathrm{SS})$ \\
\hline $\mathrm{H}$ & ARSITEK Lt.2 & & N4 & $\begin{array}{l}\text { Kusen,pintu \& } \\
\text { jendela }\end{array}$ & $\mathrm{K}(\mathrm{FS}), \mathrm{N} 3(\mathrm{SS})$ \\
\hline $\mathrm{H} 1$ & Kolom praktis & G3(FS) & N5 & $\begin{array}{l}\text { Pekerjaan } \\
\text { beton }\end{array}$ & N3(FS) \\
\hline $\mathrm{H} 2$ & Pasangan dinding & G3(FS),H1(SS)+1 & N6 & $\begin{array}{l}\text { Pekerjaan } \\
\text { Pemipaan }\end{array}$ & N3(FS) \\
\hline $\mathrm{H} 3$ & Balok Latei & G3(FS),H2(SS) & N7 & $\begin{array}{l}\text { Pek plesteran } \\
\text { dan cat }\end{array}$ & N1,N2,N4,N6(FS) \\
\hline $\mathrm{H} 4$ & Kusen,pintu \& jendela & G3(FS),H3(SS) & N8 & $\begin{array}{l}\text { Instalasi } \\
\text { pipa/sanitair }\end{array}$ & N3(FS) \\
\hline H5 & Pekerjaan beton & $\mathrm{H} 4(\mathrm{FS}), \mathrm{H} 2(\mathrm{FS})-4$ & N9 & $\begin{array}{l}\text { Pekerjaan } \\
\text { metal }\end{array}$ & N3(FS),N8(SS) \\
\hline H6 & Pekerjaan Pemipaan & $\mathrm{H} 2(\mathrm{FS})-4$ & N10 & Pekerjaan M.E & N7,N8,N9(FS) \\
\hline $\mathrm{H} 7$ & Pek plesteran dan cat & $\mathrm{H} 2(\mathrm{FS})-4$ & N11 & $\begin{array}{l}\text { Instalasi } \\
\text { telephone }\end{array}$ & N7,N8,N9(FS) \\
\hline $\mathrm{H} 8$ & Instalasi pipa/sanitair & H6(FS) & $\mathrm{N} 12$ & $\begin{array}{l}\text { Fire \& hydrant } \\
\text { alarm }\end{array}$ & N7,N8,N9(FS) \\
\hline H9 & Pekerjaan M.E & H6,H7,H8(FS) & $\mathrm{O}$ & $\begin{array}{l}\text { ARSITEK } \\
\text { LT. } 6\end{array}$ & \\
\hline $\mathrm{H} 10$ & Instalasi telephone & H6,H7,H8(FS) & $\mathrm{O} 1$ & Kolom praktis & L,M10,M11,M12(FS) \\
\hline H11 & Fire \& hydrant alarm & $\mathrm{H6}, \mathrm{H} 7, \mathrm{H} 8(\mathrm{FS})$ & $\mathrm{O} 2$ & $\begin{array}{l}\text { Pasangan } \\
\text { dinding }\end{array}$ & $\mathrm{L}(\mathrm{FS}), \mathrm{O} 1(\mathrm{SS})$ \\
\hline I & ARSITEK Lt. 3 & & $\mathrm{O} 3$ & Balok Latei & $\mathrm{L}(\mathrm{FS})$ \\
\hline $\mathrm{I} 1$ & Kolom praktis & $\mathrm{F}, \mathrm{H} 1(\mathrm{FS})$ & $\mathrm{O} 4$ & $\begin{array}{l}\text { Kusen,pintu \& } \\
\text { jendela }\end{array}$ & $\mathrm{L}(\mathrm{FS}), \mathrm{O} 3(\mathrm{SS})$ \\
\hline $\mathrm{I} 2$ & Pasangan dinding & $\mathrm{H} 1(\mathrm{FS}), \mathrm{I1}(\mathrm{SS})+1$ & $\mathrm{O} 5$ & $\begin{array}{l}\text { Pekerjaan } \\
\text { beton }\end{array}$ & $\mathrm{O} 1,02,03,04(\mathrm{FS})$ \\
\hline
\end{tabular}




\begin{tabular}{|c|c|c|c|c|c|}
\hline I3 & Balok Latei & H1(FS),I2(FF) & O6 & $\begin{array}{l}\text { Pekerjaan } \\
\text { Pemipaan }\end{array}$ & O3(FS) \\
\hline I4 & Kusen,pintu \& jendela & H1(FS),I3(SS) & O7 & $\begin{array}{l}\text { Plesteran dan } \\
\text { cat }\end{array}$ & $\mathrm{O} 3(\mathrm{FS})$ \\
\hline I5 & Pekerjaan beton & I1(FS)-2 & O8 & $\begin{array}{l}\text { Instalasi } \\
\text { pipa/sanitair }\end{array}$ & O3(FS),O6(SS) \\
\hline I6 & Pekerjaan Pemipaan & I1(FS)-1 & O9 & $\begin{array}{l}\text { Pekerjaan } \\
\text { metal }\end{array}$ & O3(FS),O8(SS) \\
\hline I7 & Pek plesteran dan cat & I1(FS)-2 & $\mathrm{O} 10$ & $\begin{array}{l}\text { Pek.langit- } \\
\text { langit }\end{array}$ & O5,06,O7(FS) \\
\hline I8 & Instalasi pipa/sanitair & I1,I6(FS) & O11 & $\begin{array}{l}\text { Pekerjaan lain- } \\
\text { lain }\end{array}$ & 07,08,09(FS) \\
\hline I9 & Pekerjaan metal & I6(FS) & $\mathrm{O} 12$ & Pekerjaan M.E & O7,08,O9(FS) \\
\hline I10 & Pekerjaan lain-lain & I7,I8,I9(FS) & $\mathrm{O} 13$ & $\begin{array}{l}\text { Instalasi } \\
\text { telephone }\end{array}$ & O12(FS) \\
\hline I11 & Pekerjaan M.E & I7,I8,I9(FS) & $\mathrm{O} 14$ & $\begin{array}{l}\text { Fire \& hydrant } \\
\text { alarm }\end{array}$ & O10,O11,O12(FS) \\
\hline I12 & Instalasi telephone & $\mathrm{I} 7, \mathrm{I} 8, \mathrm{I} 9$ (FS) & $\mathrm{P}$ & $\begin{array}{l}\text { Pek. } \\
\text { Pembersihan } \\
\text { Lap. }\end{array}$ & $\begin{array}{l}\text { G5,H3,H5,I4,I5,M3,N5,N10 } \\
\text { N11,N12,O13,O14(FS) }\end{array}$ \\
\hline
\end{tabular}

(Sumber : Data hasil perhitungan)

Tabel 3. Penentuan Nilai Deviasi Standard dan Varians

\begin{tabular}{|c|c|c|c|c|c|c|c|}
\hline No & Uraian & $\mathrm{a}$ & $\mathrm{m}$ & $\mathrm{b}$ & te & $\mathrm{S}$ & $\mathrm{V}(\mathrm{te})$ \\
\hline 1 & Pekerjaan FIA ub & & & & & & \\
\hline 2 & Pekerjaan persiapan & 7 & 10 & 14 & 10 & 1.17 & 1.36 \\
\hline 3 & Pondasi & 25 & 30 & 35 & 30 & 1.67 & 2.78 \\
\hline 4 & Struktur lt.1 & 28 & 33 & 35 & 33 & 1.17 & 1.36 \\
\hline 5 & Srtuktur lt.2 & 26 & 31 & 35 & 31 & 1.5 & 2.25 \\
\hline 6 & Struktur lt.3 & 26 & 31 & 35 & 31 & 1.5 & 2.25 \\
\hline 7 & Struktur lt.4 & 26 & 31 & 35 & 31 & 1.5 & 2.25 \\
\hline 8 & Arsitek lt.1 & & & & & & \\
\hline 9 & Pekerjaan tanah & 15 & 20 & 23 & 20 & 1.33 & 1.78 \\
\hline 10 & Pekerjaan pasangan pondasi batu kali & 8 & 12 & 16 & 12 & 1.33 & 1.78 \\
\hline 11 & Sloof dan kolom praktis & 4 & 6 & 10 & 6 & 1 & 1 \\
\hline 12 & Pekerjaaan pasangan dinding & 7 & 11 & 14 & 11 & 1.17 & 1.36 \\
\hline 13 & Balok latei & 3 & 6 & 9 & 6 & 1 & 1 \\
\hline 14 & Pekerjaan kusen, daun pintu, jendela $\&$ kaca & 4 & 6 & 10 & 6 & 1 & 1 \\
\hline 15 & Pekerjaan beton & 3 & 4 & 7 & 4 & 0.67 & 0.44 \\
\hline 16 & Pekerjaaan rioreling dan pemipaan & 3 & 4 & 7 & 4 & 0.67 & 0.44 \\
\hline 17 & Pekerjaan plesteran dan cat & 10 & 15 & 20 & 15 & 1.67 & 2.78 \\
\hline 18 & Pekerjaan instalasi pipa/sanitair & 5 & 10 & 13 & 10 & 1.33 & 1.78 \\
\hline 19 & Pekerjaan metal & 4 & 7 & 9 & 7 & 0.83 & 0.69 \\
\hline 20 & Pekerjaan m.e & 4 & 6 & 10 & 6 & 1 & 1 \\
\hline 21 & Pekerjaan instalasi telephone & 3 & 5 & 9 & 5 & 1 & 1 \\
\hline 22 & Pekerjaan fire dan hydrant alarm & 3 & 4 & 7 & 4 & 0.67 & 0.44 \\
\hline 23 & Arsitek lt.2 & & & & & & \\
\hline 24 & Kolom praktis & 4 & 5 & 8 & 5 & 0.67 & 0.44 \\
\hline 25 & Pekerjaaan pasangan dinding & 6 & 8 & 12 & 8 & 1 & 1 \\
\hline 26 & Balok latei & 3 & 4 & 7 & 4 & 0.67 & 0.44 \\
\hline 27 & Pekerjaan kusen, daun pintu, jendela $\&$ kaca & 3 & 4 & 7 & 4 & 0.67 & 0.44 \\
\hline 28 & Pekerjaan beton & 3 & 4 & 7 & 4 & 0.67 & 0.44 \\
\hline 29 & Pekerjaan pemipaan & 1 & 1 & 3 & 1 & 0.33 & 0.11 \\
\hline 30 & Pekerjaan plesteran dan cat & 10 & 15 & 19 & 15 & 1.5 & 2.25 \\
\hline 31 & Pekerjaan instalasi pipa/sanitair & 3 & 5 & 9 & 5 & 1 & 1 \\
\hline 32 & Pekerjaan m.e & 3 & 5 & 9 & 5 & 1 & 1 \\
\hline 33 & Pekerjaan instalasi telephone & 3 & 5 & 9 & 5 & 1 & 1 \\
\hline 34 & Pekerjaan fire dan hydrant alarm & 3 & 5 & 9 & 5 & 1 & 1 \\
\hline 35 & Arsitek lt.3 & & & & & & \\
\hline
\end{tabular}




\begin{tabular}{|c|c|c|c|c|c|c|c|}
\hline 36 & Kolom praktis & 5 & 6 & 9 & 6 & 0.67 & 0.44 \\
\hline 37 & Pekerjaaan pasangan dinding & 4 & 6 & 10 & 6 & 1 & 1 \\
\hline 38 & Balok latei & 3 & 4 & 7 & 4 & 0.67 & 0.44 \\
\hline 39 & Pekerjaan kusen, daun pintu, jendela \& kaca & 3 & 4 & 7 & 4 & 0.67 & 0.44 \\
\hline 40 & Pekerjaan beton & 2 & 3 & 6 & 3 & 0.67 & 0.44 \\
\hline 41 & Pekerjaan pemipaan & 1 & 1 & 3 & 1 & 0.33 & 0.11 \\
\hline 42 & Pekerjaan plesteran dan cat & 6 & 10 & 14 & 10 & 1.33 & 1.78 \\
\hline 43 & Pekerjaan instalasi pipa/sanitair & 2 & 2 & 4 & 2 & 0.33 & 0.11 \\
\hline 44 & Pekerjaan metal & 3 & 4 & 7 & 4 & 0.67 & 0.44 \\
\hline 45 & Pekerjaan lain-lain & 4 & 6 & 10 & 6 & 1 & 1 \\
\hline 46 & Pekerjaan m.e & 4 & 6 & 10 & 6 & 1 & 1 \\
\hline 47 & Pekerjaan instalasi telephone & 3 & 6 & 9 & 6 & 1 & 1 \\
\hline 48 & Pekerjaan fire dan hydrant alarm & 3 & 6 & 9 & 6 & 1 & 1 \\
\hline 49 & Struktur lt.5 & 19 & 20 & 23 & 20 & 0.67 & 0.44 \\
\hline 50 & Struktur lt.6 & 19 & 21 & 25 & 21 & 1 & 1 \\
\hline 51 & Struktur atap & 35 & 40 & 45 & 40 & 1.67 & 2.78 \\
\hline 52 & Arsitek lt. 4 & & & & & & \\
\hline 53 & Kolom praktis & 4 & 5 & 8 & 5 & 0.67 & 0.44 \\
\hline 54 & Pekerjaaan pasangan dinding & 4 & 5 & 8 & 5 & 0.67 & 0.44 \\
\hline 55 & Balok latei & 3 & 4 & 7 & 4 & 0.67 & 0.44 \\
\hline 56 & Pekerjaan kusen, daun pintu, jendela \& kaca & 3 & 4 & 7 & 4 & 0.67 & 0.44 \\
\hline 57 & Pekerjaan beton & 4 & 5 & 8 & 5 & 0.67 & 0.44 \\
\hline 58 & Pekerjaan pemipaan & 1 & 1 & 3 & 1 & 0.33 & 0.11 \\
\hline 59 & Pekerjaan plesteran dan cat & 10 & 16 & 19 & 16 & 1.5 & 2.25 \\
\hline 60 & Pekerjaan instalasi pipa/sanitair & 3 & 4 & 7 & 4 & 0.67 & 0.44 \\
\hline 61 & Pekerjaan metal & 3 & 4 & 7 & 4 & 0.67 & 0.44 \\
\hline 62 & Pekerjaan m.e & 5 & 7 & 10 & 7 & 0.83 & 0.69 \\
\hline 63 & Pekerjaan instalasi telephone & 3 & 7 & 10 & 7 & 1.17 & 1.36 \\
\hline 64 & Pekerjaan fire dan hydrant alarm & 3 & 7 & 10 & 7 & 1.17 & 1.36 \\
\hline 65 & Arsitek lt.5 & & & & & & \\
\hline 66 & Kolom praktis & 7 & 10 & 14 & 10 & 1.17 & 1.36 \\
\hline 67 & Pekerjaaan pasangan dinding & 7 & 10 & 15 & 10 & 1.33 & 1.78 \\
\hline 68 & Balok latei & 3 & 7 & 9 & 7 & 1 & 1 \\
\hline 69 & Pekerjaan kusen, daun pintu, jendela \& kaca & 7 & 10 & 14 & 10 & 1.17 & 1.36 \\
\hline 70 & Pekerjaan beton & 4 & 7 & 10 & 7 & 1 & 1 \\
\hline 71 & Pekerjaan pemipaan & 2 & 3 & 6 & 3 & 0.67 & 0.44 \\
\hline 72 & Pekerjaan plesteran dan cat & 25 & 30 & 32 & 30 & 1.17 & 1.36 \\
\hline 73 & Pekerjaan instalasi pipa/sanitair & 5 & 7 & 11 & 7 & 1 & 1 \\
\hline 74 & Pekerjaan metal & 3 & 7 & 9 & 7 & 1 & 1 \\
\hline 75 & Pekerjaan m.e & 3 & 6 & 9 & 6 & 1 & 1 \\
\hline 76 & Pekerjaan instalasi telephone & 3 & 6 & 9 & 6 & 1 & 1 \\
\hline 77 & Pekerjaan fire dan hydrant alarm & 3 & 6 & 9 & 6 & 1 & 1 \\
\hline 78 & Arsitek lt.6 & & & & & & \\
\hline 79 & Kolom praktis & 5 & 6 & 9 & 6 & 0.67 & 0.44 \\
\hline 80 & Pekerjaaan pasangan dinding & 5 & 6 & 9 & 6 & 0.67 & 0.44 \\
\hline 81 & Balok latei & 3 & 6 & 9 & 6 & 1 & 1 \\
\hline 82 & Pekerjaan kusen, daun pintu, jendela \& kaca & 4 & 6 & 10 & 6 & 1 & 1 \\
\hline 83 & Pekerjaan beton & 3 & 4 & 7 & 4 & 0.67 & 0.44 \\
\hline 84 & Pekerjaan pemipaan & 3 & 4 & 7 & 4 & 0.67 & 0.44 \\
\hline 85 & Pekerjaan plesteran dan cat & 25 & 30 & 32 & 30 & 1.17 & 1.36 \\
\hline 86 & Pekerjaan instalasi pipa/sanitair & 3 & 4 & 7 & 4 & 0.67 & 0.44 \\
\hline 87 & Pekerjaan metal & 3 & 4 & 7 & 4 & 0.67 & 0.44 \\
\hline 88 & Pekerjaan langit-langit & 5 & 7 & 11 & 7 & 1 & 1 \\
\hline 89 & Pekerjaan lain-lain & 5 & 7 & 10 & 7 & 0.83 & 0.69 \\
\hline 90 & Pekerjaan m.e & 3 & 7 & 9 & 7 & 1 & 1 \\
\hline 91 & Pekerjaan instalasi telephone & 3 & 7 & 9 & 7 & 1 & 1 \\
\hline 92 & Pekerjaan fire dan hydrant alarm & 3 & 6 & 9 & 6 & 1 & 1 \\
\hline 93 & Pekerjaan pembersihan lapangan & 3 & 6 & 10 & 6 & 1.17 & 1.36 \\
\hline
\end{tabular}

(Sumber : Data hasil perhitungan) 


\section{Analisa Jalur Kritis}

Tujuan dari tahap ini adalah untuk mengetahui hubungan dari tiap-tiap kegiatan dan menentukan jenis-jenis dari kegiatan mana sajakah yang tergolong jalur kritis. Jalur kritis adalah jalur atau urutan kegiatan yang waktu pelaksanaannya tidak boleh ditunda, karena jika sampai terlambat atau ditunda satu atau beberapa kegiatan akan mengakibatkan terlambatnya penyelesaian proyek secara keseluruhan.

Tabel 4. Penentuan Kegiatan Kritis

\begin{tabular}{|c|c|c|c|c|c|c|c|}
\hline No & Uraian & te & ES & EF & $\mathbf{L S}$ & $\mathbf{L F}$ & Float \\
\hline 1 & Pekerjaan fia ub & & & & & & \\
\hline 2 & Pekerjaan persiapan & 10 & 0 & 10 & 0 & 10 & 0 \\
\hline 3 & Pondasi & 30 & 10 & 40 & 10 & 40 & 0 \\
\hline 4 & Struktur lt.1 & 33 & 40 & 73 & 40 & 73 & 0 \\
\hline 5 & Srtuktur lt.2 & 31 & 73 & 104 & 73 & 104 & 0 \\
\hline 6 & Struktur lt. 3 & 31 & 104 & 135 & 104 & 135 & 0 \\
\hline 7 & Struktur 1t.4 & 31 & 135 & 166 & 135 & 166 & 0 \\
\hline 8 & Arsitek lt.1 & & & & & & \\
\hline 9 & Pekerjaan tanah & 20 & 135 & 155 & 194 & 214 & 59 \\
\hline 10 & Pekerjaan pasangan pondasi batu kali & 12 & 143 & 155 & 202 & 214 & 59 \\
\hline 11 & Sloof dan kolom praktis & 6 & 155 & 161 & 214 & 220 & 59 \\
\hline 12 & Pekerjaaan pasangan dinding & 11 & 155 & 166 & 214 & 225 & 59 \\
\hline 13 & Balok latei & 6 & 155 & 161 & 214 & 220 & 59 \\
\hline 14 & Pekerjaan kusen, daun pintu, jendela \& kaca & 6 & 155 & 161 & 214 & 220 & 59 \\
\hline 15 & Pekerjaan beton & 4 & 161 & 165 & 220 & 224 & 59 \\
\hline 16 & Pekerjaaan rioreling dan pemipaan & 4 & 161 & 165 & 225 & 229 & 64 \\
\hline 17 & Pekerjaan plesteran dan cat & 15 & 165 & 180 & 224 & 239 & 59 \\
\hline 18 & Pekerjaan instalasi pipa/sanitair & 10 & 165 & 175 & 229 & 239 & 64 \\
\hline 19 & Pekerjaan metal & 7 & 165 & 172 & 232 & 239 & 67 \\
\hline 20 & Pekerjaan m.e & 6 & 180 & 186 & 239 & 245 & 59 \\
\hline 21 & Pekerjaan instalasi telephone & 5 & 180 & 185 & 240 & 245 & 60 \\
\hline 22 & Pekerjaan fire dan hydrant alarm & 4 & 180 & 184 & 241 & 245 & 61 \\
\hline 23 & Arsitek lt.2 & & & & & & \\
\hline 24 & Kolom praktis & 5 & 161 & 166 & 220 & 225 & 59 \\
\hline 25 & Pekerjaaan pasangan dinding & 8 & 162 & 170 & 221 & 229 & 59 \\
\hline 26 & Balok latei & 4 & 162 & 166 & 289 & 293 & 127 \\
\hline 27 & Pekerjaan kusen, daun pintu, jendela \& kaca & 4 & 162 & 166 & 289 & 293 & 127 \\
\hline 28 & Pekerjaan beton & 4 & 166 & 170 & 293 & 297 & 127 \\
\hline 29 & Pekerjaan pemipaan & 1 & 166 & 167 & 234 & 235 & 68 \\
\hline 30 & Pekerjaan plesteran dan cat & 15 & 166 & 181 & 225 & 240 & 59 \\
\hline 31 & Pekerjaan instalasi pipa/sanitair & 5 & 167 & 172 & 235 & 240 & 68 \\
\hline 32 & Pekerjaan m.e & 5 & 181 & 186 & 240 & 245 & 59 \\
\hline 33 & Pekerjaan instalasi telephone & 5 & 181 & 186 & 240 & 245 & 59 \\
\hline 34 & Pekerjaan fire dan hydrant alarm & 5 & 181 & 186 & 240 & 245 & 59 \\
\hline 35 & Arsitek lt.3 & & & & & & \\
\hline 36 & Kolom praktis & 6 & 166 & 172 & 225 & 231 & 59 \\
\hline 37 & Pekerjaaan pasangan dinding & 6 & 167 & 173 & 291 & 297 & 124 \\
\hline 38 & Balok latei & 4 & 169 & 173 & 293 & 297 & 124 \\
\hline 39 & Pekerjaan kusen, daun pintu, jendela \& kaca & 4 & 169 & 173 & 293 & 297 & 124 \\
\hline 40 & Pekerjaan beton & 3 & 170 & 173 & 294 & 297 & 124 \\
\hline 41 & Pekerjaan pemipaan & 1 & 171 & 172 & 234 & 235 & 63 \\
\hline 42 & Pekerjaan plesteran dan cat & 10 & 170 & 180 & 229 & 239 & 59 \\
\hline 43 & Pekerjaan instalasi pipa/sanitair & 2 & 172 & 174 & 237 & 239 & 65 \\
\hline 44 & Pekerjaan metal & 4 & 172 & 176 & 235 & 239 & 63 \\
\hline 45 & Pekerjaan lain-lain & 6 & 180 & 186 & 239 & 245 & 59 \\
\hline 46 & Pekerjaan m.e & 6 & 180 & 186 & 239 & 245 & 59 \\
\hline 47 & Pekerjaan instalasi telephone & 6 & 180 & 186 & 239 & 245 & 59 \\
\hline
\end{tabular}




\begin{tabular}{|c|c|c|c|c|c|c|c|}
\hline 48 & Pekerjaan fire dan hydrant alarm & 6 & 180 & 186 & 239 & 245 & 59 \\
\hline 49 & Struktur lt.5 & 20 & 166 & 186 & 166 & 186 & 0 \\
\hline 50 & Struktur 1t.6 & 21 & 186 & 207 & 186 & 207 & 0 \\
\hline 51 & Struktur atap & 40 & 207 & 247 & 207 & 247 & 0 \\
\hline 52 & Arsitek lt.4 & & & & & & \\
\hline 53 & Kolom praktis & 5 & 186 & 191 & 245 & 250 & 59 \\
\hline 54 & Pekerjaaan pasangan dinding & 5 & 186 & 191 & 245 & 250 & 59 \\
\hline 55 & Balok latei & 4 & 186 & 190 & 245 & 249 & 59 \\
\hline 56 & Pekerjaan kusen, daun pintu, jendela $\&$ kaca & 4 & 186 & 190 & 245 & 249 & 59 \\
\hline 57 & Pekerjaan beton & 5 & 186 & 191 & 245 & 250 & 59 \\
\hline 58 & Pekerjaan pemipaan & 1 & 190 & 191 & 249 & 250 & 59 \\
\hline 59 & Pekerjaan plesteran dan cat & 16 & 191 & 207 & 250 & 266 & 59 \\
\hline 60 & Pekerjaan instalasi pipa/sanitair & 4 & 190 & 194 & 262 & 266 & 72 \\
\hline 61 & Pekerjaan metal & 4 & 190 & 194 & 262 & 266 & 72 \\
\hline 62 & Pekerjaan m.e & 7 & 207 & 214 & 266 & 273 & 59 \\
\hline 63 & Pekerjaan instalasi telephone & 7 & 207 & 214 & 266 & 273 & 59 \\
\hline 64 & Pekerjaan fire dan hydrant alarm & 7 & 207 & 214 & 266 & 273 & 59 \\
\hline 65 & Arsitek lt.5 & & & & & & \\
\hline 66 & Kolom praktis & 10 & 207 & 217 & 251 & 261 & 44 \\
\hline 67 & Pekerjaaan pasangan dinding & 10 & 207 & 217 & 251 & 261 & 44 \\
\hline 68 & Balok latei & 7 & 207 & 214 & 251 & 258 & 44 \\
\hline 69 & Pekerjaan kusen, daun pintu, jendela \& kaca & 10 & 207 & 217 & 251 & 261 & 44 \\
\hline 70 & Pekerjaan beton & 7 & 214 & 221 & 290 & 297 & 76 \\
\hline 71 & Pekerjaan pemipaan & 3 & 214 & 217 & 258 & 261 & 44 \\
\hline 72 & Pekerjaan plesteran dan cat & 30 & 217 & 247 & 261 & 291 & 44 \\
\hline 73 & Pekerjaan instalasi pipa/sanitair & 7 & 214 & 221 & 284 & 291 & 70 \\
\hline 74 & Pekerjaan metal & 7 & 214 & 221 & 284 & 291 & 70 \\
\hline 75 & Pekerjaan m.e & 6 & 247 & 253 & 291 & 297 & 44 \\
\hline 76 & Pekerjaan instalasi telephone & 6 & 247 & 253 & 291 & 297 & 44 \\
\hline 77 & Pekerjaan fire dan hydrant alarm & 6 & 247 & 253 & 291 & 297 & 44 \\
\hline 78 & Arsitek lt. 6 & & & & & & \\
\hline 79 & Kolom praktis & 6 & 247 & 253 & 273 & 279 & 26 \\
\hline 80 & Pekerjaaan pasangan dinding & 6 & 247 & 253 & 273 & 279 & 26 \\
\hline 81 & Balok latei & 6 & 247 & 253 & 247 & 253 & 0 \\
\hline 82 & Pekerjaan kusen, daun pintu, jendela \& kaca & 6 & 247 & 253 & 273 & 279 & 26 \\
\hline 83 & Pekerjaan beton & 4 & 253 & 257 & 279 & 283 & 26 \\
\hline 84 & Pekerjaan pemipaan & 4 & 253 & 257 & 279 & 283 & 26 \\
\hline 85 & Pekerjaan plesteran dan cat & 30 & 253 & 283 & 253 & 283 & 0 \\
\hline 86 & Pekerjaan instalasi pipa/sanitair & 4 & 253 & 257 & 279 & 283 & 26 \\
\hline 87 & Pekerjaan metal & 4 & 253 & 257 & 279 & 283 & 26 \\
\hline 88 & Pekerjaan langit-langit & 7 & 283 & 290 & 284 & 291 & 1 \\
\hline 89 & Pekerjaan lain-lain & 7 & 283 & 290 & 284 & 291 & 1 \\
\hline 90 & Pekerjaan m.e & 7 & 283 & 290 & 283 & 290 & 0 \\
\hline 91 & Pekerjaan instalasi telephone & 7 & 290 & 297 & 290 & 297 & 0 \\
\hline 92 & Pekerjaan fire dan hydrant alarm & 6 & 290 & 296 & 291 & 297 & 1 \\
\hline 93 & Pek. Pemb. Lapangan & 6 & 297 & 303 & 297 & 303 & 0 \\
\hline
\end{tabular}

(Sumber : Data hasil perhitungan)

Dari tabel 4 yang tergolong jalur kritis adalah kegiatan yang waktu tunda Slack/Floatnya sama dengan nol $(\mathrm{LS}-\mathrm{ES}=\mathrm{LF}-\mathrm{EF}=0$ ). Kegiatan yang termasuk dalam jalur kritis yaitu kegiatan dengan nomor 2-3-4-5-6-7-49-50-51-81-85-90-91-93 (yang floatnya sama dengan nol). Jumlah kumulatif waktu/ durasi kegiatan yang termasuk kedalam kegiatan kritis adalah 303 hari kerja.
Sedangkan dari tabel 5 diketahui bahwa (TE)93 adalah jumlah kumulatif kurun waktu dari pekerjaan-pekerjaan kritis, yakni sebesar 303 hari. Sedangkan dari tabel diatas dapat diketahui pula Varians dari pekerjaan-pekerjaan kritis, yaitu :

$$
\begin{aligned}
& V(\text { TE })-93=V(\text { TE })-1+V(\text { te })-2+V(\text { te })-3+ \\
& V(\text { te })-4+V(\text { te })-5+V(\text { te })-6+V(\text { te })-7+V(\text { te })-
\end{aligned}
$$




$$
\begin{aligned}
& 49+V(\text { te })-50+V(\text { te })-51+V(\text { te })-81+V(\text { te })- \\
& 85+V(\text { te })-90+V(\text { te })-91+V(\text { te })-93=0+ \\
& 1.36+2.78+1.36+2.25+2.25+2.25+0.44 \\
& +1.00+2.78+1.00+1.36+1.00+1.00+ \\
& 1.36=22,19
\end{aligned}
$$

Dengan total Varians V (TE) $-93=22,19$, maka $S=\sqrt{22,19}=4,7$ atau $3 \mathrm{~S}=14,19$. Diperoleh harga $3 \mathrm{~S}=14,19$. maka didapatkan kurun waktu penyelesaian proyek sebesar $303 \pm 14,19$ hari.

Dari uraian diatas diambil jawaban untuk kurun waktu penyelesaian proyek paling cepat adalah 303 $-14,19=288,81$ hari dan penyelesaian proyek paling lambat adalah $303+14,19=317,19$ hari.

\section{Analisa Target Waktu Penyelesaian Proyek T(d)}

- Jika dimisalkan target penyelesaian pada hari $\mathrm{Td}=303-4,71=298,29$

$\mathrm{Z}=\frac{T(d)-\tau E}{s}=\frac{298,29-303}{4.71}=-1$

Dengan nilai $\mathrm{z}=-1$, maka diperoleh angka probabilitas sebesar 0.1587 , hal ini berarti kemungkinan proyek selesai pada $\mathrm{Td}=$ 298,29adalah sebesar $16 \%$.

- Jika dimisalkan target penyelesaian pada hari $\mathrm{Td}=303$

$\mathrm{Z}=\frac{T(d)-T E}{s}=\frac{349-349}{4.71}=0$

Dengan nilai $\mathrm{z}=0$, maka diperoleh angka probabilitas sebesar 0.5000 , hal ini berarti kemungkinan proyek selesai pada $\mathrm{Td}=303$ adalah sebesar $50 \%$.

- Jika dimisalkan target penyelesaian pada hari $\mathrm{Td}=303+14,13=317,13$

$\mathrm{Z}=\frac{\tau(\mathrm{d})-\tau E}{s}=\frac{317,13-303:}{4,71}=3$

Dengan nilai $z=3$, maka diperoleh angka probabilitas sebesar 0.998650 , hal ini berarti kemungkinan proyek selesai pada $\mathrm{Td}=317,13$ adalah sebesar 99\%.

\section{KESIMPULAN DAN SARAN}

- Perencanaan waktu penyelesaiaan proyek yang optimal dengan menggunakan metode PERT dan PDM yaitu selama 303 hari dengan total biaya sebesar Rp 16,278,036,000.00 (termasuk didalamnya keuntungan kontraktor + PPN $10 \%$ ).

- Kurun waktu penyelesaian proyek selama 303 hari sudah optimal ditinjau dari penggunaan SDM yang berupa tenaga kerja proyek yang optimal. Dikatakan optimal karena penggunaan tenaga kerja proyek yang merata/tidak fluktuatif dan jika disajikan dalam bentuk grafik menghasilkan kurva mendekati distribusi normal.

- Dari hasil perhitungan analisa target waktu penyelesaian proyek $\mathrm{T}(\mathrm{d})$, menunjukkan bahwa kemungkinan proyek selesai pada durasi/kurun waktu 303 hari (waktu normal) hanya sebesar $50 \%$. Sedangkan jika durasi/ kurun waktu penyelesaiaan proyek ditambah $3 \mathrm{~S}$ (tiga kali simpangan baku) yaitu $303+14,13$ hari $=317,13$ hari, maka kemungkinan proyek selesai pada durasi/kurun waktu 317,13 hari sebesar 99\%. Jadi untuk merencanakan suatu penjadwalan proyek hendaknya kurun waktu total proyek ditambahkan $3 \mathrm{~S}$ (tiga kali simpangan baku) sehingga kemungkinan target penyelesaian proyek mencapai persentase $99 \%$ (aman/tidak terlambat).

\section{DAFTAR PUSTAKA}

Diphohusodo, Istimawan. Manajemen Proyek dan Konstruksi Jilid I.Kanisius. Yogyagarta.1996. ErviantoWulfram I. Teori Aplikasi Manajemen Proyek Konstruksi. Andi Offset. Yogyakarta.2004.

Nugraha, Paulus, Ishak, Natan, Sucipto. Manajemen Proyek Konstruksi I. Kartika Yudha. Surabaya. 1985.

Soeharto, Iman. Manajemen Proyek dari Konseptual Sampai Operasional. Jilid 1.Erlangga..Jakarta.1995. 